\section{Tribute to Professor Naomich Arima}

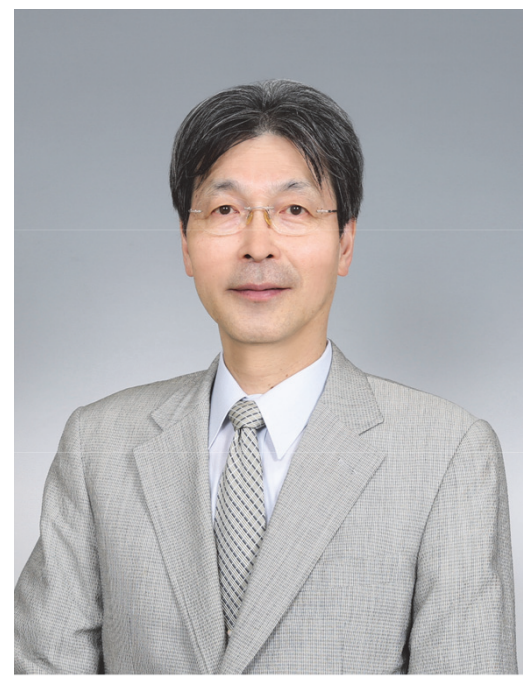

Professor Naomichi Arima's work schedule would intimidate just about anyone, especially if one is unfamiliar with the Japanese work ethic; but even the Japanese themselves would be impressed by his stamina. He was always busy; as one would say in Japan, neko no te mo karitai gurai isogashii (so busy one would appreciate borrowing even a cat's paw as a helping hand). Professor Arima, my sensei, mentor, friend, would arrive at work early when he would usually catch up on his emails; he would head to the Hematology/Immunology clinic where he cared for patients with disorders of the blood or immune system, or conduct ward rounds; lecture undergraduate and graduate medical students; chair meetings as Department Head, and would walk into the laboratory at the end of the day to do an experiment, such as a Western blot to look at proteins or tend to cancer cell lines he was establishing from a patient's cells; and he did it effortlessly, without even a bead of sweat above his eyebrows. Inspired by him, I knew that was the kind of physician-scientist I wanted to become. He conducted basic science research or 'bench work' identifying new anti-cancer drugs, and led clinical trials that resulted in improved treatment modalities for patients with adult $\mathrm{T}$ cell leukaemia/lymphoma (ATLL), a cancer of the blood and one of the most aggressive cancers one could imagine.

I met Professor Arima during the $12^{\text {th }}$ International Conference on Human Retrovirology June 22 to 25, 2005 convened in Montego Bay, a tourist resort on the North Coast of Jamaica. During that Conference, I also met his post-doctoral research fellow at the time who had made a most intriguing presentation about research being conducted in Professor Arima's lab; as we say in Japan jitsuni omoshirokata (very interesting). Jamaica, like Japan, has a high prevalence of the human T-cell lymphotropic virus type I (HTLV-1), with about $6 \%$ of Jamaicans harbouring this virus. Ninety-five per cent of the carriers of this virus develop no symptoms; but a few go on to develop a leukaemia or cancer of the blood or a paralyzing disease called HTLV-1 associated myelopathy/ tropical spastic paraparesis (HAM/TSP), Eric Cruickshank former Head of Medicine and The University of the West Indies, Mona, Jamaica was the first to explore on the unusual paralysis. Interestingly, Japanese patients with this virus, if they do develop disease, will tend to develop the leukaemia; but Jamaican patients would tend to develop the paralysis instead, and this has been ascribed to the genetic differences that impact the way our bodies respond to this unique virus. Two years later, I joined Professor Arima's laboratory in Kagoshima City, Southern Japan as a Kenkyusei or research student with the intention of spending 18 months, but was inspired by him to enroll in the Doctor of Philosophy programme, spending some five years in Japan. We wrote papers together, did experiments together and shared a patent for a novel anticancer drug we discovered together. He is an intellectual giant of a man who is by far one of the most humble people I have ever known.

As he retires this year from Kagoshima University, I salute my sensei, and salute the countless Associate Professors, medical doctors and researchers whom he has mentored and inspired, and who will continue his work. Arigatou gozaimashita (thank you).

\section{$Y$ White}

From: U.S. Military HIV Research Program (MHRP); HJF Viral Genetics Section, Walter Reed Army Institute of Research, Silver Spring, Maryland, USA.

Correspondence: Dr Y White, US Military HIV Research Program (MHRP), HJF Viral Genetics Section, Walter Reed Army Institute of Research, 503 Robert Grant Avenue, Room 2A46, Silver Spring, MD 20910, Maryland, USA.Email:ywhite@hivresearch.org 